Société d'histoire de la révolution de 1848 et des

révolutions du XIXe siècle

$24 \mid 2002$

Varia

\title{
Matthew KNEALE, Les Passagers anglais
}

traduit de l'anglais par Georges-Michel Sarotte. Paris, Belfond, 2002, 448 p., $21,50 €$.

\section{Fabrice Bensimon}

\section{OpenEdition}

\section{Journals}

Édition électronique

URL : http://journals.openedition.org/rh19/396

DOI : $10.4000 /$ rh19.396

ISSN : $1777-5329$

\section{Éditeur}

La Société de 1848

\section{Édition imprimée}

Date de publication : 1 juin 2002

Pagination : 204-205

ISSN : 1265-1354

\section{Référence électronique}

Fabrice Bensimon, "Matthew KNEALE, Les Passagers anglais », Revue d'histoire du XIXe siècle [En ligne],

24 | 2002, mis en ligne le 04 juin 2003, consulté le 22 septembre 2020. URL : http://

journals.openedition.org/rh19/396 ; DOI : https://doi.org/10.4000/rh19.396

Ce document a été généré automatiquement le 22 septembre 2020.

Tous droits réservés 


\section{Matthew KNEALE, Les Passagers anglais}

traduit de l'anglais par Georges-Michel Sarotte. Paris, Belfond, 2002, 448 p., $21,50 €$.

Fabrice Bensimon

1857. Mettez dans un vaisseau un équipage gaélique de l'île de Man (située entre l'Angleterre et l'Irlande), sous la houlette du capitaine Kewley, qui fait dans la contrebande d'alcool et de tabac, navigue sans cartes et n'a jamais fait de voyage au long cours. Ajoutez-y un pasteur, le révérend Wilson, en croisade contre les "géologues athées", convaincu d'avoir localisé en Tasmanie le jardin d'Eden, et entendant --pour faire taire les railleries-- le prouver, au prix d'un voyage sur place. Rajoutez à cet équipée déjà mal assortie le docteur Potter, un médecin anglais qui rédige un traité sur la hiérarchie entre les types nationaux et les races, et entreprend, pour étayer son propos, de collecter des corps de "sauvages". Tels sont les principaux ingrédients de l'expédition qui se dirige, à travers mille péripéties, vers la Tasmanie.

Cette île grande comme l'Irlande, située au sud de l'Australie, avait été découverte en 1642 par le navigateur hollandais Abel Tasman. À partir de 1803, les Anglais l'occupèrent. Ils y établirent une colonie pénitentiaire et y exterminèrent progressivement les quelque 4000 Mélanésiens qui peuplaient l'île à leur arrivée. Parmi les forçats, les nationalistes irlandais côtoyaient les déportés de droit commun.

Jusqu'en 1856, l'île était encore appelée "terre de Van Diemen", du nom du gouverneur général des îles néerlandaises au moment de sa découverte, avant que les Anglais n'en changent le nom, tant la réputation de la colonie était déplorable.

C'est un des autres points de vue de ce roman historique érudit : à travers le regard de Peevay, un Aborigène, on voit les Anglais s'installer, développer l'élevage du mouton, enclore les terres, parquer les Mélanésiens dans une réserve crasseuse, et les massacrer quand ils offrent une résistance. Les Anglais bienveillants ne se comportent pas mieux que les criminels endurcis. La rencontre entre les deux groupes est la ligne de fuite du roman.

Pour l'écrire, l'anglais Matthew Kneale s'est immergé dans les conceptions religieuses, philosophiques et (pseudo-) scientifiques de l'époque. Grâce au contact de sources 
primaires, il a échappé aux anachronismes fréquents de ce type d'ouvrage. Kneale est parvenu à restituer le point de vue de chacun des principaux protagonistes : le roman est en effet composé d'extraits de journaux privés et de lettres de plus de 20 personnages différents, avec des préoccupations, des styles, des points de vue divers et souvent contradictoires. Nourri d'une réflexion sur la colonisation, sur le racisme, sur la religion, le récit tient en haleine le lecteur de la première à la dernière page ; l'humour et la verve de l'écriture, rendus avec fidélité et talent par le traducteur, s'ajoutent à ces qualités pour faire des Passagers anglais un grand roman historique. 